\title{
Kako načiniti kristale limunske kiseline i šećera
}

\section{Sikirica*}

Zavod za opću i anorgansku kemiju, Kemijski odsjek, Prirodoslovno-matematički fakultet, Horvatovac 102A, HR-10 000 Zagreb

\begin{abstract}
Sažetak
Učenici osnovnih škola gotovo redovito izvode pokus krstalizacije modre galice i kuhinjske soli. Modra galica je otrovna i štetna za okoliš, a veće kristale kuhinjske soli teško je dobiti. Umjesto pokusa kristalizacije modre galice i kuhinjske soli bolje je izvesti pokus kristalizacije limunske kiseline i običnoga šećera. Te su tvari jeftine, lako dostupne, biorazgradljive i nisu štetne za okoliš.

Ključne riječi

Nastava kemije, limunska kiselina, šećer, pokus, kristal, kristalizacija, kristalna rešetka, kristalna struktura, jedinična ćelija kristalne rešetke, simetrija
\end{abstract}

\section{Uvod}

Jedna od obvezatnih nastavnih aktivnosti u predmetu Kemija za učenike 7. razreda osnovne škole jest kristalizacija. Iskustvo je pokazalo da učitelji i učenici kao primjer kristalizacije najčešće izvode pokus kristalizacije modre galice i kuhinjske soli.

Postavlja se pitanje je li takav izbor pokusa najbolji? Modra galica je otrovna i štetna za okoliš. Skupa je i nabavlja se u poljoprivrednim ljekarnama uz posebnu iskaznicu. Kuhinjska sol je jeftina, ali je veće monokristale (jedinične kristale) teško dobiti. Umjesto pokusa kristalizacije modre galice i kuhinjske soli, bolje je izvesti pokus kristalizacije limunske kiseline i običnoga šećera. Šećera ima u svakom kućanstvu, a limunska se kiselina može nabaviti u većim trgovinama prehrambenih proizvoda u pakiranjima od 100, 200 ili 500 g. Neotrovna je i potpuno biorazgradljiva te nije štetna za okoliš. Prirodno je sadržana u mnogim vrstama voća. Dopušteni je aditiv, E330, u ekološkoj proizvodnji hrane. Redoviti je sastojak mnogih bezalkoholnih pića, voćnih sirupa, džemova, želea, marmelada, pekmeza i ostalih sličnih voćnih proizvoda.

Uzgoj kristala šećera i limunske kiseline može biti zabavna izvanškolska aktivnost. Svi potrebni sastojci i "laboratorijski pribor" nalaze se u svakoj kuhinji. No takva zabavna aktivnost ima važnu odgojno-obrazovnu ulogu u razvoju djeteta jer potiče znatiželju, razvija vještinu rada s "kemikalijama", razvija sposobnost uočavanja promjena, potiče samostalnost u rješavanju problema te donošenju zaklju-

${ }^{*}$ Prof. dr. sc. Milan Sikirica

e-pošta: sikirica@chem.pmf.hr čaka i odluka tijekom izvođenja pokusa. Nadalje, učenici mogu na nastavi kemije pokazati kristale i izvijestiti o rezultatima svojih istraživanja putem plakata ili softverskih alata kao što su PowerPoint, Prezi, Moovly, Google Presentations i slično. Unatoč brojnim softverskim alatima i općoj sklonosti digitalizaciji svega, ne treba zanemariti običan plakat, usmeno izlaganje i razgovor. Plakat je odlično sredstvo za usavršavanje vlastita likovnog izraza. Usmeno izlaganje pak pridonosi vještini govorništva, a putem razgovora s drugim učenicima u razredu uči se "pregovarati" s drugima na društveno prihvatljiv način. Kroz razgovor mogu se zajednički utvrditi činjenice i otkriti pravilo ili zakonitost koja objašnjava rezultate pokusa. Tako se uči razmjenjivati ideje, pri čemu se razvija sposobnost suradnje (timski rad), što je bitno za uspjeh u stvarnome svijetu.

U većini škola uobičajene su izložbe učeničkih radova na kojima se, osim ostalog, mogu izložiti kristali šećera ili limunske kiseline i time potaknuti veći interes za kristale, kristalografiju, mineralogiju i geologiju. Takvo događanje može biti povod obnavljanju, uređivanju ili nadopunjavanju zbirki minerala i fosila koje postoje, ili su nekad postojale, u većini osnovnih škola. ${ }^{1}$

\section{Što su kristali}

Riječ kristal potječe od grčke riječi krystallos. Ta se riječ nekad odnosila uglavnom na led i kvarc. Ako lupom ili mikroskopom pogledate kuhinjsku sol, uočit ćete kristaliće u formi (obliku) kocke. Svi kristali običnoga šećera, bez obzira na to gdje su proizvedeni, imaju istu formu. Ako slučajno naiđete na nebrušene kristale dijamanta, iako ne vjerujem 
da će vam se to dogoditi, uočit ćete da imaju formu oktaedra. Veća je vjerojatnost da ćete na sajmu minerala za nekolko kuna kupiti kristale fluorita, $\mathrm{CaF}_{2}$, koji također imaju formu oktaedra, ili kristale pirita, $\mathrm{FeS}_{2}$, koji imaju formu kocke. Kristali berila, $\mathrm{Be}_{3} \mathrm{Al}_{2} \mathrm{Si}_{6} \mathrm{O}_{18}$, imaju formu heksagonske prizme. Lijepo razvijeni kristali, koje nalazimo u prirodi, uvijek su omeđeni ravnim plohama i oblikom podsjećaju na neko geometrijsko tijelo. Na temelju studije velikoga broja kristala kvarca danski anatom i geolog Niels Stensen (1638. - 1686.), poznatiji po latiniziranom imenu Nicolaus Stenonius ili Nicolaus Steno, otkrio je 1669. godine da svi kristali iste tvari, bez obzira na njihov različit izgled ili nalazište, uvijek imaju istu geometrijsku formu i pokazuju istovjetne kutove između susjednih kristalnih ploha. To je svojstvo karakteristično za kristale svake tvari te je poznato kao zakon stalnosti kutova ili prvi zakon kristalografije.

Francuski mineralog René Just Haüy (1743. - 1822.) začetnik je moderne kristalografije. Njegov interes za kristalografiju javio se nakon što mu je slučajno ispao i razbio se kristal kalcita, $\mathrm{CaCO}_{3}$. Skupljajući razbijene komadiće uočio je sličnost njihova oblika. Promatrajući fragmente, uočio je da se kristali kalcita kalaju tako da tvore ravne plohe koje se sijeku pod stalnim kutovima. Ustanovio je da, bez obzira na izvorni oblik, dobiveni fragmenti uvijek imaju formu romboedra. Na temelju tih opažanja zaključio je da su svi kristali izgrađeni od manjih kemijski identičnih poliedara koje je nazvao molekule sastavljačice (franc. molécule intégrantes). Haüy je prvi uočio periodičnost unutarnje građe kristala što je opisao u svojim knjigama. Pritom je pokazao kako slaganjem kemijski identičnih građevnih jedinki, poliedara, odnosno molekula sastavljačica, nastaju različite ravne plohe na kristalu.

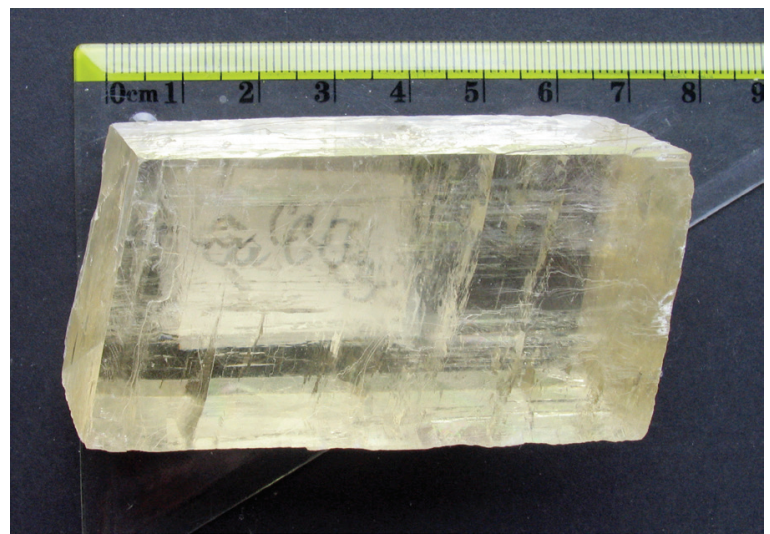

Slika 1 - Kristali kalcita, $\mathrm{CaCO}_{3}$, imaju zanimljivo svojstvo dvoloma. Dvolom je pojava koju pokazuju neke tvari u kojima se upadna zraka svjetlosti pri lomu razdvaja u dvije zrake, ordinarnu i ekstraordinarnu (redovitu i izvanrednu). Te zrake kroz kristal putuju različitim brzinama. Zbog dvoloma objekti promatrani kroz proziran kristal kalcita vide se dvostruko.

Fig. 1 - Calcite crystals, $\mathrm{CaCO}_{3}$, have an interesting property of birefringence. Birefringence is a phenomenon that is shown by some substances in which the incident ray of light is split into two rays, ordinary and extraordinary. These rays travel through the crystal at different speeds. This birefringence causes objects viewed through a clear piece of calcite to appear doubled.
Proučavajući kristale nađene u prirodi, već su srednjovjekovni kristalografi uočili njihov stalan kemijski sastav. Nadalje, uočili su i simetrijske elemente na kristalima; ravnine, osi i centar simetrije. Kristal ima simetrijsku ravninu ako se nekom zamišljenom ravninom može podijeliti na dvije polovine koje se odnose kao predmet i slika u zrcalu. Simetrijska os jest zamišljeni pravac oko kojega se rotacijom kristala za kut $2 \pi / n(n=2,3,4,6)$ vide iste plohe, bridovi i vrhovi kakvi se na kristalu vide prije rotacije. Kristal ima centar simetrije kad se svakoj plohi na kristalu može pronaći odgovarajuća usporedna ploha na suprotnoj strani kristala. Možemo zamisliti jednu točku u središtu kristala kroz koju se preslikavaju plohe, bridovi i vrhovi kristala. Ta se točka naziva centrom simetrije. To znači da svaka točka na površini ili unutrašnjosti kristala ima svoj centrosimetrični par na jednakoj udaljenosti, ali u suprotnom smjeru od centra simetrije. No ima i kristala bez ijednog simetrijskog elementa. Na temelju tih opažanja lako je bilo pretpostaviti da je pravilnost u vanjskom izgledu kristala posljedica uređenoga unutarnjeg razmještaja njihovih građevnih jedinki, atoma, iona i molekula.

Zadatak: Načinite kocku od papira i na njoj pronađite simetrijske elemente: 3 glavne simetrijske ravnine, 6 sporednih simetrijskih ravnina, 3 simetrijske osi četvrtoga reda, 4 simetrijske osi trećega reda i 6 simetrijskih osi drugoga reda. Načinite od papira i oktaedar (to je model prirodnog dijamanta koji vjerojatno nećete naći) te na njemu potražite iste simetrijske elemente. Imaju li kocka i oktaedar jednake ili različite simetrijske elemente? (Odgovor: jednake)

Danas se pod pojmom kristal i kristalna tvar razumije krutina građena od atoma, iona ili molekula čiji se pravilan raspored periodično ponavlja u tri smjera u prostoru. Pravilan raspored građevnih jedinki termodinamički je najstabilniji. Zato je kristalno stanje krutina pravilo, dok je amorfno stanje iznimka. Kristalni lusteri, vaze, čaše i "kristalne kugle" gatara i vidovnjaka nisu kristali, već staklo. Njihove su građevne jedinke kaotično raspoređene kao u tekućini. Istini za volju, i u amorfnim krutinama, kao i u staklima i tekućinama, postoji uređen razmještaj građevnih jedinki, ali samo na kratkom razmaku koji seže do udaljenosti od nekoliko atoma ili molekula. Naprotiv, u kristalima uređeni razmještaj građevnih jedinki proteže se kroz cijeli kristal i periodično se ponavlja u tri smjera u prostoru.

Kristalna rešetka je zamišljeni prostorni raspored točaka u kojemu se, polazeći iz bilo koje točke u istovrsnu točku u prostoru, može doći translacijom (lat. translatio - prijenos) uzduž određenih smjerova. Da bismo jednoznačno definirali rešetku, moramo znati smjer u kojemu se istovrsni razmještaj periodično ponavlja i udaljenost na kojoj se u tom smjeru dolazi u istovrsnu točku. Taj se smjer zove translacijska os ili os kristalne rešetke, a duljina periodičnoga ponavljanja jest period kristalne rešetke. Tri smjera translacije u prostoru, odnosno tri osi kristalne rešetke, kao i njihove periode, označujemo slovima $a, b, c$, a kutove što ih osi međusobno zatvaraju označujemo grčkim slovima 

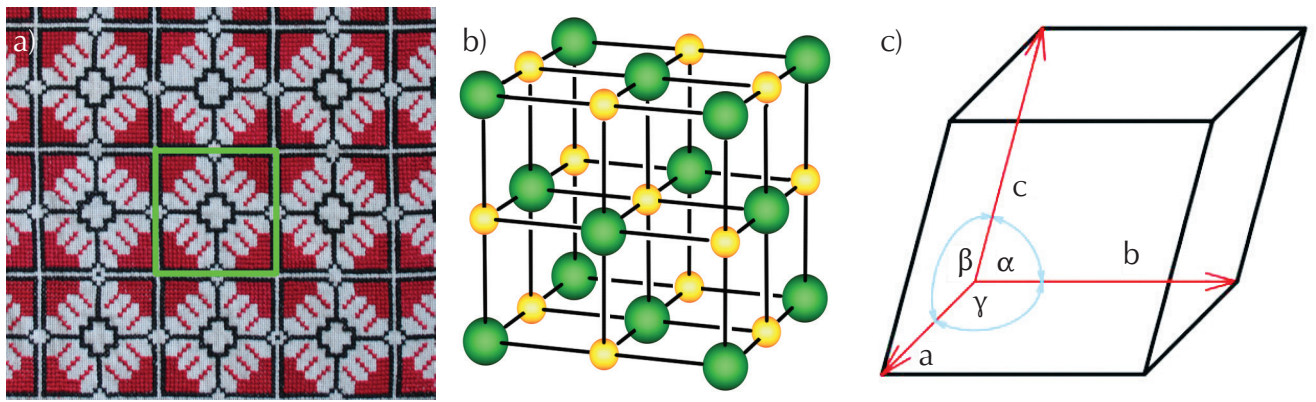

Slika 2 - a) Na ovom ručnom radu, inspiriranom tradicijom, zeleni kvadrat označuje jediničnu ćeliju koja se periodično ponavlja u dva smjera u ravnini. b) Kristali su trodimenzijske tvorevine pa se istovrsni razmještaj atoma, iona ili molekula periodično ponavlja u tri smjera u prostoru. Slika shematski prikazuje jediničnu ćeliju kristala natrijeva klorida. c) Jedinična ćelija definirana je sa šest parametara: tri brida ( $a, b$ i c), i kutovima među njima $(\alpha, \beta$ i $\gamma)$.

Fig. 2 - a) In this manual work, inspired by tradition, the green square indicates a unit cell repeated periodically in two directions in the plane. b) Crystals are three-dimensional formations, and the same arrangement of atoms, ions or molecules, is periodically repeated in three directions in the space. The picture schematically shows the unit cell of the sodium chloride crystal. c) A unit cell of a crystal is characterized by six parameters; three edges ( $a, b$, and c) and angles between them $(\alpha, \beta$, and $\gamma)$.

alfa $(\alpha)$, beta $(\beta)$ i gama $(\gamma)$. Kristalna rešetka natrijeva klorida je kubna, pa su sve tri osi jednake duljine a kutovi među osima $90^{\circ}$. Kristalnu strukturu kemijskog elementa ili spoja dobijemo tako da svakoj točki kristalne rešetke pridružimo atom, ion ili molekulu. Dakle, kristalnom rešetkom opisujemo zakonitost po kojoj se razmještaj atoma, iona ili molekula periodički ponavlja u prostoru.

\section{Kako nastaju kristali}

U prirodi kristali mogu nastati na mnogo načina. Najvažniji proces je kristalizacija magme. Magma je taljevina koja se nalazi ispod Zemljine kore te se najvećim dijelom sastoji od oksida silicija, aluminija, alkalijskih i zemnoalkalijskih elemenata (natrija, kalija, kalcija, magnezija) i željeza. Iz magme kristalizira većina tzv. primarnih petrogenih minerala kao što su silikati, kremen i neki rudni minerali. Kristali mogu nastati i iz hladnih vodenih otopina, primjerice kamena sol i gips. Sulfidi, selenidi, teluridi, arsenidi, antimonidi i neki drugi rudni minerali nastaju iz vrućih vodenih otopina, pa se za njih kaže da su hidrotermičkoga podrijetla. Kristali mogu nastati i kristalizacijom iz plinova, primjerice snježne pahulje iz vodene pare i kristali sumpora iz vulkanskih plinova.

\section{Pokusi}

U školskim uvjetima najlakše je izvesti kristalizaciju iz zasićenih vodenih otopina. Otopina je zasićena kad pri danoj temperaturi ne može otopiti daljnje količine tvari. ${ }^{2}$ No topljivost većine tvari povećava se porastom temperature. Kad se topla zasićena otopina postupno hladi, pri nižoj temperaturi koncentracija otopljene tvari je veća od ravnotežne, pa nastaje prezasićena otopina. Prezasićene otopine su termodinamički nestabilne, pa se višak otopljene tvari kristalizira. Prezasićena otopina može nastati i isparavanjem otapala. Zasićenu otopinu treba ostaviti na mirnu mjestu stalne temperature. Otapalo, u našem slučaju voda, polagano isparava, pa nastane prezasićena otopina iz koje kristalizira višak otopljene tvari.

No neke prezasićene otopine, primjerice običnoga šećera i limunske kiseline, ponekad treba "cijepiti" sitnim kristalićima kako bi se potaknula kristalizacija. Ako se u prezasićenu otopinu uroni samo jedan manji kristalić, primjerice limunske kiseline, velika je vjerojatnost da će on tijekom vremena izrasti u znatno veći kristal. U prirodi tvari najčešće kristaliziraju u obliku agregata (nakupina) a rijetko u obliku monokristala. Bez obzira na izgled dobivenih kristala njihova je unutarnja građa uvijek ista i svojstvena samo toj tvari.

\section{Pokus 1. Monokristal limunske kiseline ${ }^{3}$}

Pribor: 2 staklenke za konzerviranje povrća, visoki lonac od 2 I, lijevak, filtrirni papir, drveni štapić od sladoleda, najlonski konac ili flaks, limunska kiselina, destilirana voda.

\section{Postupak:}

1. U staklenku za konzerviranje povrća uspite $500 \mathrm{~g}$ limunske kiseline i dolijte $250 \mathrm{ml}$ destilirane vode ugrijane na oko $40{ }^{\circ} \mathrm{C}$. Uočite promjenu temperature dobivene otopine.

2. Načinite vodenu kupelj tako da lonac do polovine njegove visine napunite vodovodnom vodom. Prenesite staklenku s limunskom kiselinom u vodenu kupelj i ugrijte je na oko $50{ }^{\circ} \mathrm{C}$. Miješajte dugačkom metalnom žlicom dok se sva kiselina ne otopi. Topljivost limunske kiseline u vodi jako se povećava porastom temperature.

3. Vodenu kupelj, zajedno sa staklenkom otopine limunske kiseline, ostavite da se "preko noći" spontano 
ohladi na sobnu temperaturu. Pritom će se na dnu staklenke izlučiti kristali limunske kiseline. Količina izlučenih kristala ovisi o temperaturi okoline.

4. Dobivenu zasićenu otopinu profiltrirajte u čistu staklenku. Kao filtrirni papir možete upotrijebiti papirnati ubrus ili jastučić od vate.

5. Kristale zaostale u staklenki prenesite i raširite u plitkoj posudi ili tanjuru s tamnim dnom. Pincetom odaberite jedan od ljepših kristala limunske kiseline i odmah ga obrišite papirnatim ubrusom. Ostatak kristala limunske kiseline sačuvajte za ponovljene pokuse.

6. Odabrani kristalić, kristalnu jezgru, zavežite tankim najlonskim koncem ili tankim flaksom kakav rabe ribiči. Slobodan kraj konca zavežite na štapić od sladoleda.

7. Uronite kristalnu jezgru u profiltriranu zasićenu otopinu limunske kiseline. Okretanjem štapića od sladoleda namotaje višak konca toliko da se kristalna jezgra nađe u sredini zasićene otopine limunske kiseline.

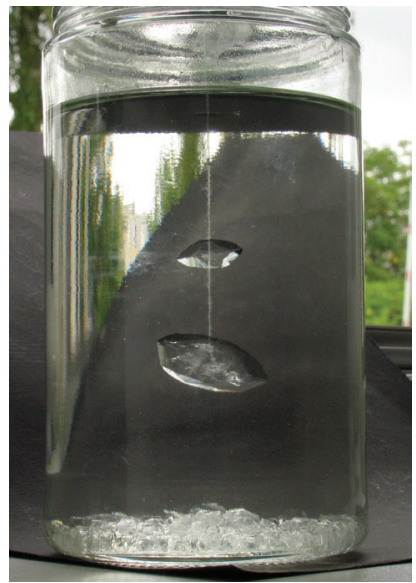

Slika 3 - Kristalne jezgre u zasićenoj otopini limunske kiseline Fig. 3 - Seed crystals in saturated citric acid solution

8. Staklenku sa zasićenom otopinom i kristalnom jezgrom limunske kiseline postavite na mirno mjesto sa stalnom temperaturom, najbolje u neku podrumsku prostoriju. Otvor staklenke ovlaš prekrijte papirnatim ubrusom, ali tako da se omogući protok zraka a spriječi padanje prašine u otopinu. Oboružajte se strpljenjem. Veliki i lijepi kristali u prirodi rasli su tisućama godina.

9. Povremeno razbijte koru od kristala koja nastaje na površini zbog isparavanja otopine. Parazitske kristale koji nastaju na niti zdrobite drškom metalne žlice pritiskom na stjenku staklenke. Izdvojite bistru zasićenu otopinu i prenesite kristal u drugu čistu staklenku. Po potrebi činite to svaka dva-tri tjedna.

10. Kad kristal dovoljno naraste izvadite ga iz zasićene otopine i odmah obrišite papirnatim ubrusom. Osušeni kristal odmah premažite bezbojnim lakom za nok- te. Tako zaštićen kristal mogu razgledati i drugi učenici u razredu te na njemu uočiti ravne plohe, bridove, uglove i simetrijske elemente.

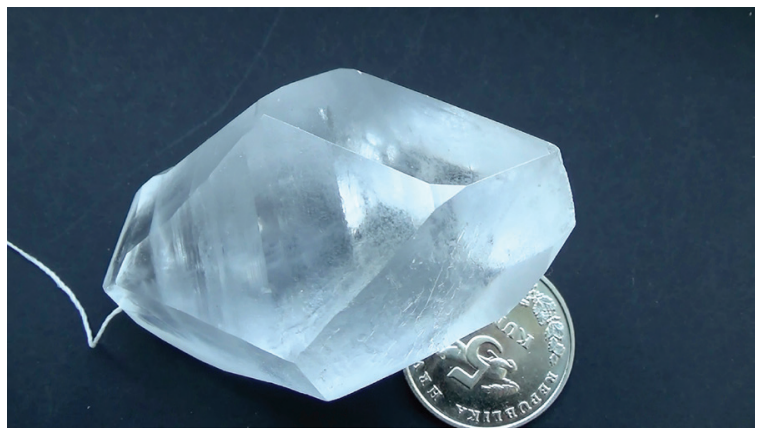

Slika 4 - Monokristal (jedinični kristal) limunske kiseline Fig. 4 - A single crystal of citric acid

\section{Pokus 2. Kristali običnoga šećera - saharoze 4,5}

Pribor: manja staklenka za konzerviranje povrća, visoki lonac od 1 I, dugačka žličica, drveni štapić, pamučni konac, kristalni šećer, destilirana voda.

Postupak:

1. U manju staklenku za konzerviranje povrća uspite 250 g kristalnoga šećera i $80 \mathrm{ml}$ destilirane vode. Staklenku stavite u lonac s vodom koji će poslužiti kao vodena kupelj. Zagrijte vodenu kupelj do vrenja vode a sadržaj staklenke miješajte sve dok se sav šećer ne otopi. Šećer je jako topljiv u vodi a povišenjem temperature topljivost mu se povećava. Smjesu šećera i vode nikad ne zagrijavajte u metalnoj posudi neposredno na plamenu jer će se pri povišenoj temperaturi šećer rastaliti i karamelizirati. Kad se sav šećer otopi, vodenu kupelj zajedno sa staklenkom ostavite na mirnu mjestu da se "preko noći" spontano ohladi. Tako ćete dobiti prezasićenu otopinu šećera u vodi.

2. Dio drvenog štapića, kakav se rabi za ražnjiće, prstom namažite prezasićenom otopinom šećera. Navlažene dijelove štapića pospite s nekoliko kristalića šećera. Držite štapić na toplomu mjestu tako da se sirup osuši i kristalići šećera učvrste na površini štapića a potom uronite u staklenku s ohlađenom prezasićenom otopinom. Prezasićene otopine šećera, primjerice med, teško spontano kristaliziraju, pa ih treba "cijepiti" kristalićima šećera koji služe kao centri kristalizacije.

3. Tijekom jednoga tjedna ili dulje štapić će se obložiti krupnim kristalima šećera. Tako ćete dobiti jedinstvenu i neponovljivu lizalicu. Lizalicu vrlo kratko isperite mlazom vodovodne vode i posušite papirnatim ubrusom.

4. Otkinite najljepši kristal s lizalice i zavežite ga tankim flaksom kakav rabe ribiči. Kristal objesite u preostalu prezasićenu otopinu šećera i on će tijekom nekoliko idućih tjedana porasti. Ostatak sirupa nemojte baciti. Možete ga iskoristiti za pripremu limunade i dr. 


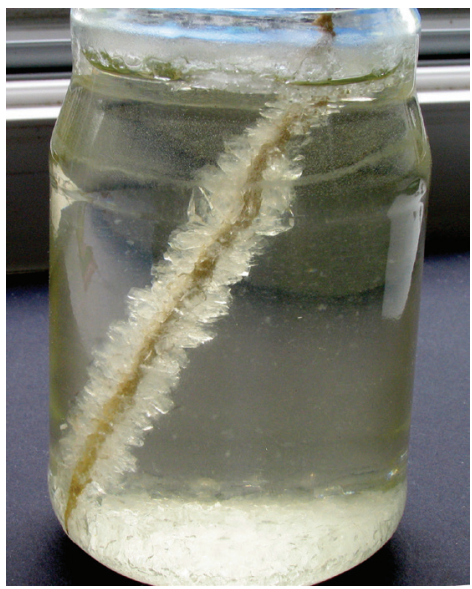

Slika 5 - Nakon jednoga tjedna drveni se štapić obložio kristalima saharoze

Fig. 5 - After a week, the wooden stick was covered with sucrose crystals

\section{Čemu služe kristali}

"Dijamanti su najbolji djevojčini prijatelji" pjevala je Marylin Monroe, ali ona je o dijamantima samo to znala. Od svih iskopanih dijamanata samo manji dio ima takvu kvalitetu da se može iskoristiti za nakit. Većina nađenih dijamanata rabi se $u$ industriji kao nezamjenjiv dio alata za rezanje, bušenje, brušenje i poliranje. Za industrijske svrhe dijamanti se od 1955. godine proizvode i umjetnim putem.

No suvremena djeca, djevojke, mladići, obični i poslovni ljudi, inženjeri i znanstvenici danas bi rekli da su računala i mobiteli naši najbolji prijatelji. Ali računala i mobitela ne bi bilo bez kristala, ponajprije kristala kvarca i silicija.

Francuski fizičari i braća Jacques Curie (1855. - 1941.) i Pierre Curie (1859. - 1906.) otkrili su 1880. godine da se pri mehaničkom pritisku na plohama nekih kristala (npr. kvarca, topaza, turmalina) javlja električni naboj. Ta je pojava poznata kao piezoelektrični efekt (grč. piezo = tiskati). U kristalu kvarca u neopterećenom stanju, ioni silicija i kisika su u električnoj i geometrijskoj ravnoteži. Kad se na kristal kvarca primijeni sila, dolazi do pomaka iona silicija i kisika, pa se geometrijska i električna ravnoteža naruši. Zato se na plohama kristala javlja razlika električnoga potencijala. No događa se i obrnuto. Ako se na pločicu od kvarca, izrezanu određenim smjerom iz kristala, prilijepe metalne elektrode i na njih priključi električni napon, pločica će se raširiti ili stegnuti ovisno o polaritetu napona. To se svojstvo kvarca primjenjuje u kristalnim mikrofonima, kristalnim slušalicama, sonarima, oscilatorima elektroničkih uređaja i dr. ${ }^{6}$ Sam kvarcni kristal nije oscilator, nego je bitan dio svakoga titrajnog kruga, primjerice u kvarcnim satovima, odašiljačima TV i radiovalova, radioaparatima, mobitelima, računalima i svim uređajima koji rade na nekoj zadanoj frekvenciji. Primjerice, antenu vašega mobite- la zapljuskuju radiovalovi svih mogućih frekvencija, ali će titrajni krug (oscilator) s kristalićem kvarca propustiti i pojačati samo onaj signal čija je frekvencija jednaka vlastitoj frekvenciji titrajnoga kruga u vašem mobitelu. Danas gotovo ne postoji elektronički uređaj bez kvarcnoga oscilatora.

Za potrebe elektroničke industrije godišnje se proizvede preko 3000 tona monokristala kvarca. Proizvode se hidrotermičkim postupkom u autoklavima pri tlaku od 130 do $145 \mathrm{MPa} .^{7}$ Autoklav je podijeljen u dva dijela. U donjem dijelu krhotine prirodnoga kvarca otapaju se u lužnatoj vodenoj otopini $\left(w(\mathrm{NaOH})=0,02, w\left(\mathrm{Na}_{2} \mathrm{CO}_{3}\right)=0,03\right)$ pri temperaturi od 380 do $400{ }^{\circ} \mathrm{C}$, pri čemu nastaje zasićena otopina. Zbog razlike temperature zasićena otopina struji u gornji hladniji dio autoklava gdje je temperatura 300 do $320{ }^{\circ} \mathrm{C}$. Pri nižoj temperaturi otopina postaje prezasićena, pa $\mathrm{SiO}_{2}$ kristalizira na malim jezgrama izrezanim iz kristala kvarca. Tako se dobiju veliki monokristali potrebni elektroničkoj industriji.

No signal koji je propustio titrajni krug s kristalom kvarca treba pojačati, a tu najvažniju ulogu imaju kristali silicija od kojih se proizvode tranzistori i čipovi. Monokristali silicija dobivaju se iz rastaljena silicija čistoće 99,999999999\%. Prema metodi poljskoga kemičara J. Czochralskoga (1885. - 1953.) jezgrom od monokristala silicija dotakne se rastaljeni silicij (talište $1414{ }^{\circ} \mathrm{C}$ ) u kvarcnomu loncu. ${ }^{8}$ $\mathrm{Na}$ mjestu dodira od kristalne jezgre (engl. seed crystal) počinje kristalizacija u dubinu i širinu taline. Vrlo polaganim i jednolikim podizanjem kristalne jezgre, uz istodobnu rotaciju, dobiju se monokristali iste kristalne orijentacije kao u početnoj jezgri. Za potrebe industrije čipova danas se tom metodom proizvode monokristali silicija promjera $400 \mathrm{~mm}$ i duljine preko $2 \mathrm{~m}$. Da bi se spriječila oksidacija silicija, kristalizacija se izvodi u atmosferi argona. No nečistoće iz kvarcnoga lonca mogu prijeći u rastaljeni silicij, što snižava kvalitetu dobivenoga monokristala. Zato se za posebne svrhe monokristali silicija dobivaju metodom lebdeće zone (engl. floating zone), pri čemu rastaljeni silicij ne dolazi u dodir s drugim materijalima. ${ }^{9}$

\section{Zaključak}

Nisu samo kristali kvarca i silicija zanimljivi znanstvenicima i tehnolozima. Velika većina tvari je u kristalnom stanju, primjerice sve stijene i minerali, cement i većina materijala koji se rabe u građevinarstvu, svi metali i njihove slitine, svi praškasti lijekovi i još mnogo toga. Istraživanje kristala i njihovih kristalnih struktura dovodi do novih spoznaja koje omogućuju dobivanje boljih građevinskih materijala, kvalitetnijih slitina, boljih lijekova i dr. Znanstvenici danas znaju kristalizirati proteine i viruse te odrediti njihovu građu. To pomaže razumijevanju kemijskih i biokemijskih procesa koji se događaju u našem organizmu, uočavanju uzroka nekih bolesti i nalaženju metoda njihova liječenja.

Danas živimo u informatičkom dobu koje je nastalo zahvaljujući znanstvenim istraživanjima kristala i njihovih svojstava. Već spomenuti kristali kvarca i silicija najbolje svjedoče o važnosti istraživanja i primjene znanja za teh- 
nološki razvoj. Naime, maseni udio silicija u Zemljinoj kori iznosi oko $28 \%$, a kvarcnog pijeska ima posvuda te je dostupan svakome. No samo one države koje su imale odgovarajuće znanje, tehnologiju i viziju mogle su iz pijeska proizvesti kristale kvarca i silicija te izmisliti, usavršiti i danas proizvoditi mikroprocesore. Bez mikroprocesora ne bi bilo naših omiljenih mobitela i računala, koja upravljaju svime, od proizvodnje čačkalica do kretanja robota na površini Marsa. Zemlje koje zanemaruju znanost i ne unaprjeđuju tehnologiju osuđene su na gubitak tehnologije i ovisnost o tehnološki razvijenim zemljama. Zato već u osnovnoj školi kod učenika treba poticati znatiželju a nastavni proces voditi tako da učenici nova znanja i sposobnosti stječu vlastitim aktivnostima. Na djelu je nova obrazovna paradigma (obrazac). Današnji učitelji ne moraju više znati sve o svemu. Oni uče zajedno s učenicima i jedni od drugih, jer znanje više nužno ne teče od starijih prema mlađima, već od onih koji nešto znaju prema onima koji to još ne znaju.

\section{Literatura \\ References}

1. URL: https://www.iycr2014.org/_data/assets/pdf_ file/0011/85457/CG brochure.pdf (26. 6. 2019.).

2. M. Sikirica, Zbirka kemijskih pokusa, Školska knjiga, Zagreb, 2011., str. 159-169.

3. URL: https://www.youtube.com/watch? $=\mathrm{GH} 2 \mathrm{fWr}$ ZfB3Y\&t=4s (26. 6. 2019.).

4. M. Sikirica, 77 kuhinjskih pokusa, Školska knjiga, Zagreb, 2014., str. 118-125.

5. URL: https://sciencenotes.org/how-to-make-rock-candy-orsugar-crystals/ (26. 6. 2019.).

6. URL: https://www.scribd.com/doc/83063689/Kristalni-Oscilator-Wiki-3 (26. 6. 2019.).

7. URL: https://www.youtube.com/watch?v=PFyL3ZjuE9E (26. 6. 2019.).

8. URL: https://link.springer.com/chapter/10.1007/978-3-319-48933-9_13 (26. 6. 2019.).

9. URL: http://meroli.web.cern.ch/Lecture_silicon_floatzone czochralski.html (26. 6. 2019.).

\section{SUMMARY}

\section{How to Make Citric Acid and Sugar Crystals}

Milan Sikirica

Middle school students almost regularly perform experiments of crystallization of copper(II) sulphate pentahydrate and kitchen salt. Copper(II) sulphate pentahydrate is poisonous and harmful to the environment, and larger crystals of kitchen salt are difficult to obtain. Instead of experimenting with the crystallization of copper(II) sulphate pentahydrate and kitchen salt, it is better to carry out crystallization of citric acid and common (table) sugar. These materials are inexpensive, easily accessible, biodegradable, and not environmentally hazardous.

\section{Keywords}

Chemical education, citric acid, sugar, experiment, crystal, crystallization, crystal lattice, crystal structure, unit cell, symmetry

Division of General and Inorganic

Chemistry

Department of Chemistry

Faculty of Science, University of Zagreb

Horvatovac 102a

10000 Zagreb, Croatia
Professional paper Received June 25, 2019 Accepted July 31, 2019 